Burushaskicae", glance at broader issues. Others, however, such as the contributions by Dr. T. Grahame Bailey or Prof. A. Barannikov, to name two only, which deal with the relation of the Sanskritic to other elements in the vernaculars, or Dr. F. Otto Shrader on the Uralian element in the Drāvidā and the Munda tongues, have a direct interest for those who are dealing with current problems in Indian ethnology; while the value of linguistic studies in cultural investigation is shown by such inquiries as those of Prof. J. Block on the character of the Vedic plough and the late Dr. J. Charpentier on the meaning of 'Śakudhūma' and the suggestion arising therefrom as to ritual recognition of the Pleiades in Vedic times. It is remarkable, however, how on every side there is evidence that in these investigations the work of Sir George Grierson and his linguistic survey of India have been fundamental.

\section{Chemical Society: Annual General Meeting}

THE ninety-fifth annual general meeting of the Chemical Society was held under the presidency of Prof. N. V. Sidgwick in the University of Bristol on Thursday, April 16. Fellows and their guests were received by Dr. Stanley H. Badock, treasurer and pro-chancellor of the University. At the annual general meeting, it was reported that the following had been elected on the Council : As vice-presidents who have filled the office of president: Prof. H. E. Armstrong and Sir William Pope. As vice-presidents who have not filled the office of president : Mr. J. Davidson Pratt, Sir Robert Robertson and Prof. R. Robinson. As honorary secretary : Prof. J. W. Cook. As ordinary members of council : Town Members : Prof. C. K. Ingold, Dr. R. P. Linstead and Dr. R. E. Slade. Country Members: Prof. G. R. Clemo, Mr. T. W. J. Taylor and Prof. R. V. Wheeler. The presidential address delivered by Prof. Sidgwick was on "Structural Chemistry: Old and Now".

THE Longstaff Medal for 1936 of the Chemical Society was presented to Prof. George Barger, and in making the presentation the president stated that it was the highest distinction which the Society could bestow on one of its fellows. He referred to the importance of Prof. Barger's researches on natural products of physiological interest, mentioning his researches on ergot and its constituents, and to Prof. Barger's work in increasing our knowledge of a large number of alkaloids, many of which he had synthesised. In presenting the Harrison Memorial Prize for 1935 to Dr. Leslie E. Sutton, the president remarked that the prize, which was founded in memory of an eminent fellow of the Society who gave his life to the service of his country in the Great War, is awarded every three years to the chemist less than thirty years of age who has made the most meritorious original contributions to chemical science. The president referred to Dr. Sutton's work in increasing our knowledge of molecular structure, which has helped to elucidate the formulæ of divalent carbon compounds, the oximes and the azides; he also referred to his work on the relation between dipole moment and substitution in benzene derivatives, and on electron diffraction. The anniversary dinner of the Society was held in the Great Hall of the University of Bristol on the evening of April 16. Prof. N. V. Sidgwick presided; and the number present was 158. The Hantzsch Memorial Lecture was delivered by Prof. T. S. Moore in the H. H. Wills Physics Lecture Theatre of the University of Bristol on Friday, April 17.

\section{British Society for International Bibliography}

THe eighth ordinary meeting of the British Society for International Bibliography was held in the Science Museum, South Kensington, on March 25. After the president, Prof. A. F. C. Pollard, had opened the meeting, Dr. Van Heurn, director of the Intelligence Bureau of the Amsterdam Laboratories of the Royal Dutch Petroleum Co., gave a description of the work and organisation of this Bureau. The secretary of the Society, Mr. E. Lancaster-Jones, followed with an account of the progress of the English edition of the Universal Decimal Classification. He reported that the first fascicule of the work is now available, while the second will be ready very shortly. Messrs. Simpkin Marshall, Ltd., are the British agents. The main item on the agendaa discussion on the preparation of indexes to periodical bibliographies and allied publications-then followed. This was opened by Dr. P. S. Hudson, deputy director of the Imperial Bureau of Plant Genetics at Cambridge, who described the preparation of the yearly cumulative indexes to Plant Breeding $A b$. stracts, the quarterly publication of his Bureau. The abstracts are classified by the Universal Decimal Classification; hence the preparation of the index, in which the entries are arranged in numerical order of their classification numbers, is extremely simple.

DR. A. S. NEAVE, assistant director of the Imperial Institute of Entomology, then spoke on the alphabetical index to the Review of Applied Entomology, pointing out the advantages of this type of index over a numerical one, in the particular case of this subject, with its extremely detailed nomenclature and its somewhat volatile systematisation. The discussion following centred around the relative advantages of a classification as the basis of an index. Dr. S. C. Bradford contended that most alphabetical indexes are based on concealed classifications. Mr. W. T. Astbury instanced the difficulty of obtaining uniformity in alphabetical indexing among a number of contributors. It was pointed out that a classified index in no wise precludes the employment of ex. planatory terms, or standard nomenclature. The classification itself possesses an alphabetical index, which serves automatically to correlate all synonyms to a unique class symbol, and thereby saves unnecessary repetition.

\section{The Reclamation of the Zuider Zee}

THE epoch-making enterprise on which the Dutch nation embarked in 1920 , and which is ultimately destined to add to the Netherlands more than half a 